\title{
Short-term responses of ecosystem carbon fluxes to experimental soil warming at the Swiss alpine treeline
}

\author{
Frank Hagedorn · Melissa Martin · Christian Rixen • \\ Silvan Rusch · Peter Bebi · Alois Zürcher · Rolf T. W. Siegwolf • \\ Sonja Wipf $\cdot$ Christophe Escape $\cdot$ Jacques Roy $\cdot$ Stephan Hättenschwiler
}

Received: 17 November 2008/Accepted: 12 February 2009/Published online: 1 April 2009

(C) Springer Science+Business Media B.V. 2009

\begin{abstract}
Climatic warming will probably have particularly large impacts on carbon fluxes in high altitude and latitude ecosystems due to their great stocks of labile soil $\mathrm{C}$ and high temperature sensitivity. At the alpine treeline, we experimentally warmed undisturbed soils by $4 \mathrm{~K}$ for one growing season with heating cables at the soil surface and measured the response of net $\mathrm{C}$ uptake by plants, of soil respiration, and of leaching of dissolved organic carbon (DOC). Soil warming increased soil $\mathrm{CO}_{2}$ effluxes instantaneously and throughout the whole vegetation period $\left(+45 \%\right.$; +120 $\left.\mathrm{g} \mathrm{C} \mathrm{m} \mathrm{y}^{-1}\right)$. In contrast, DOC leaching showed a negligible response of a $5 \%$ increase (NS). Annual C uptake of new shoots was not significantly affected by elevated soil temperatures, with a 17, 12, and 14\% increase for larch, pine, and dwarf shrubs, respectively, resulting in an
\end{abstract}

F. Hagedorn $(\bowtie) \cdot S$. Rusch $\cdot$ A. Zürcher $\cdot$ S. Wipf Swiss Federal Institute for Forest, Snow and Landscape Research (WSL), 8093 Birmensdorf, Switzerland e-mail: hagedorn@wsl.ch

M. Martin - C. Rixen · P. Bebi

WSL Institute for Snow and Avalanche Research SLF, Flüelastrasse 11, 7260 Davos, Switzerland

R. T. W. Siegwolf

Paul-Scherrer Institut, 5232 Villigen-PSI, Switzerland

C. Escape · J. Roy $\cdot$ S. Hättenschwiler

Centre of Functional Ecology and Evolution, CEFE-

CNRS, 1919 route de Mende, 34293 Montpellier, France overall increase in net $\mathrm{C}$ uptake by plants of 20-40 $\mathrm{g} \mathrm{C} \mathrm{m}^{-2} \mathrm{y}^{-1}$. The $Q_{10}$ of 3.0 measured for soil respiration did not change compared to a 3-year period before the warming treatment started, suggesting little impact of warming-induced lower soil moisture $(-15 \%$ relative decrease) or increased soil $\mathrm{C}$ losses. The fraction of recent plant-derived $\mathrm{C}$ in soil respired $\mathrm{CO}_{2}$ from warmed soils was smaller than that from control soils ( 25 vs. $40 \%$ of total C respired), which implies that the warming-induced increase in soil $\mathrm{CO}_{2}$ efflux resulted mainly from mineralization of older SOM rather than from stimulated root respiration. In summary, one season of $4 \mathrm{~K}$ soil warming, representative of hot years, led to $\mathrm{C}$ losses from the studied alpine treeline ecosystem by increasing SOM decomposition more than $\mathrm{C}$ gains through plant growth.

Keywords Carbon - Climate change .

Dissolved organic carbon - Soil organic matter .

Soil respiration - Stable isotopes .

Temperature $\cdot$ Treeline

\section{Introduction}

Feedbacks between terrestrial ecosystems and the ongoing climatic changes are one of the key uncertainties in predicting global warming (Davidson and Janssens 2006; Heimann and Reichstein 2008). Although the effects of rising temperatures on single 
processes have been studied intensively, a comprehensive understanding of whole ecosystem responses to global warming still remains elusive (see metaanalysis by Rustad et al. 2001). Arctic and alpine regions are likely to be particularly affected by climate warming because observed temperature increases in these areas are higher than anywhere else (IPCC 2007; Rebetez and Reinhard 2008). Moreover, high latitude/altitude ecosystems might be more sensitive than other types of ecosystems because plant growth is often limited by low temperature (Körner 1998), and soil respiration is more sensitive to warming at lower temperatures (Kirschbaum 1995). In addition, high latitude/altitude ecosystems store the greatest fraction of their carbon stocks in soils (IPCC 2007), and compared to temperate ecosystems, cold soils were found to comprise more labile soil organic matter (SOM) because decomposition and humification proceses are slow (Jenny 1926; Sjögersten et al. 2003).

Plant growth responses to increased temperature have been studied in situ in both arctic (see review by Dormann and Woodin 2002) and alpine (Kudo and Suzuki 2003) ecosystems. Results indicate delayed growth stimulation by 2 or more years after initiation of warming in these ecosystems dominated by slowgrowing plants of determinate growth (Shaver et al. 1986; Parsons et al. 1994). The magnitude of growth responses and thus of net $\mathrm{C}$ uptake rates, however, have been found to be highly ecosystem and plant species specific (e.g., Hartley et al. 1999). As the alpine treeline has received little attention in experimental warming studies (but see Danby and Hik 2007), growth responses to warming in these ecosystems remain largely unknown.

Since temperature drives soil respiration rates (Davidson and Janssens 2006), we might expect increasing $\mathrm{C}$ losses from ecosystems under climatic warming. The stimulation of soil respiration by increased temperatures, however, could be counterbalanced by changing carbon inputs from plants (Oberbauer et al. 2007), by declining soil moisture (Saleska et al. 1999), by an 'acclimatization' through physiologically adapting microbial communities, or by declining resource availability (Luo et al. 2001; Melillo et al. 2002). Moreover, soil respiration is essentially driven by recent photosynthates (Högberg et al. 2001), and thus, the response of soil $\mathrm{CO}_{2}$ effluxes to rising temperatures also depends on how plants and their $\mathrm{C}$ allocation to below-ground sinks respond to warming (Schindlbacher et al. 2009).

In contrast to soil respiration, little is known about the temperature dependency of DOC leaching as the second major pathway of $\mathrm{C}$ loss from ecosystems (Harrison et al. 2008). Although DOC production is at least partly microbial driven, concentrations of DOC in the field are generally only weakly related to temperature since (1) water fluxes are important codrivers (2) inputs of fresh litter vary across seasons (3) DOC is a net product of DOC generation and consumption, and (4) DOC is also released by physico-chemical processes (Michalzik et al. 2001). Laboratory and soil transplant studies using 'undisturbed' soil columns suggest that the $Q_{10}$ of DOC production is much lower than that of soil respiration (Christ and David 1996; Harrison et al. 2008). However, interpretation of these short-term experiments is limited by the physical disturbance of soils during sampling.

Although $\mathrm{C}$ fluxes between ecosystems and the atmosphere have been studied intensively, the reasons for intra-annual variability and the responses to extreme meteorological conditions, such as the hot and dry year 2003, are still not well understood (Ciais et al. 2005; Heimann and Reichstein 2008). A promising approach to improve our knowledge of the complex impacts of climatic changes and of climate variability is the in situ manipulation of climatic conditions. So far, experimental warming in colder climates has mainly occurred at high latitudes (Oechel et al. 1993; Oberbauer et al. 2007) and in boreal forests (Niinistö et al. 2004; Bronson et al. 2008). Results indicate ecosystem-dependent responses in $\mathrm{C}$ fluxes with initial $\mathrm{C}$ losses in dry tundra and boreal forests, but dampened effects under anoxic conditions. The only study at high altitude was done in a dry alpine meadow in Colorado, and showed that soil heating had stronger indirect than direct effects on soil $\mathrm{C}$ cycling by changing plant species composition and inducing moisture limitations for soil respiration (Saleska et al. 1999).

Our study aimed at estimating how carbon fluxes in alpine treeline ecosystems with undisturbed soils and thick organic layers respond to in situ soil warming. In our experiment, we warmed soils by a constant $4 \mathrm{~K}$ throughout the snow-free period with heating cables laid out on the soil surface. The soil warming was conducted within a long-term $\mathrm{CO}_{2}$ 
enrichment study, which provides a unique ${ }^{13} \mathrm{C}$ label for recent plant-derived $\mathrm{C}$ in soils. Our objectives were (1) to estimate the in situ temperature dependency of soil respiration and DOC leaching (2) to determine if soil warming induces a moisture limitation for soil $\mathrm{C}$ fluxes and plant growth; and (3) to quantify how the 1-year warming treatment, as a proxy for hot years, affects the $\mathrm{C}$ balance of alpine treelines.

\section{Materials and methods}

Study site description

The soil warming study was carried out at Stillberg (2,180 $\mathrm{m}$ a.s.l.) in the Central Alps near Davos, Switzerland, where a long-term research site was established in the late 1950s to study climate-growth relationships (Senn and Schönenberger 2001). Longterm average annual precipitation is $1,050 \mathrm{~mm}$, mean maximum snow depth is $1.50 \mathrm{~m}$, mean annual temperature is $1.4^{\circ} \mathrm{C}$, and average January and July temperatures are $-5.8^{\circ} \mathrm{C}$ and $9.4^{\circ} \mathrm{C}$, respectively. The terrain is rather steep, with slopes of $25-30^{\circ}$ facing north-east. Parent material is Paragneiss. Soil types are sandy Ranker and Podzols (Lithic Cryumbrepts and Typic Cryorthods). The organic layers are Humimors dominated by $5-20 \mathrm{~cm}$ thick $\mathrm{Oa}$ horizons (Bednorz et al. 2000; Hagedorn et al. 2008). Soil characteristics are given in Table 1.

\section{Experimental set-up}

The combined $\mathrm{CO}_{2}$ enrichment-soil warming experiment was conducted at the upper end of an afforestation experiment established in 1975 slightly above the natural treeline. Three treeline species, Larix decidua L., Pinus cembra L., and Pinus uncinata Ramond, were planted across an area of 5 ha spanning an altitudinal range of 2,080-2,230 $\mathrm{m}$ a.s.l. Thirty-two years later, the trees at the upper end of the plantation are currently approximately $2 \mathrm{~m}$ tall and they form a sparse open canopy with dense understory vegetation composed predominantly of ericaceous dwarf shrubs, such as Vaccinium myrtillus, Vaccinium uliginosum, and Empetrum hermaphroditum, and of common herbaceous species, such as Gentiana punctata, Homogyne alpina, and Melampyrum pratense.

\section{$\mathrm{CO}_{2}$ enrichment}

In 2001, we established experimental $\mathrm{CO}_{2}$ enrichment within a relatively homogeneous $2,500 \mathrm{~m}^{2}$ area (Hättenschwiler et al. 2002). Forty plots, each with an individual Larix or Pinus tree in the centre and at least $1 \mathrm{~m}$ apart from each other, were organized into 10 groups of four neighbouring plots to facilitate logistics of $\mathrm{CO}_{2}$ distribution and regulation. Five of these ten groups were randomly assigned to an elevated $\mathrm{CO}_{2}$ treatment, while the remaining groups served as controls, resulting in a split-plot design. The 20 elevated $\mathrm{CO}_{2}$ plots were enriched with $\mathrm{CO}_{2}$ using a FACE-set-up, in which pure $\mathrm{CO}_{2}$ is released through 24 vertically hanging laser-punched drip irrigation tubes fixed on steel frames enclosing an area of $1.1 \mathrm{~m}^{2}$ (Hättenschwiler et al. 2002). Concentrations of $\mathrm{CO}_{2}$ were recorded every $10 \mathrm{~min}$ in all cardinal points in one plot per group. These concentrations were used to adjust the $\mathrm{CO}_{2}$ addition. The multiple-year growing season average of $\mathrm{CO}_{2}$ concentration was $566 \pm 75 \mathrm{ppm}_{\mathrm{v}}$ under elevated $\mathrm{CO}_{2}$ and $370 \pm 3 \mathrm{ppm}_{\mathrm{v}}$ under ambient $\mathrm{CO}_{2}$ (see Hättenschwiler et al. 2002; Handa et al. 2006). In
Table 1 Soil properties of the treeline ecosystem at 2,200 m a.s.1., Stillberg, Switzerland

\footnotetext{
${ }^{a}$ Fine earth per volume soil

b Particle sizes $>63 \mu \mathrm{m}$
}

\begin{tabular}{lllllll}
\hline Horizon & $\begin{array}{l}\text { Depth } \\
(\mathrm{cm})\end{array}$ & $\begin{array}{l}\text { Soil density }^{\mathrm{a}} \\
\left(\mathrm{g} \mathrm{cm}^{-3}\right)\end{array}$ & $\begin{array}{l}\text { Fraction sand }^{\mathrm{b}} \\
(\%)\end{array}$ & $\begin{array}{l}\mathrm{pH} \\
\left(\mathrm{CaCl}_{2}\right)\end{array}$ & $\begin{array}{l}\text { Soil organic } \\
\mathrm{C}(\%)\end{array}$ & $\begin{array}{l}\text { C/N mass } \\
\text { ratio }\end{array}$ \\
\hline $\mathrm{Oi}$ & $7-6$ & 0.07 & $\mathrm{ND}$ & $\mathrm{ND}$ & 46.3 & 46.2 \\
$\mathrm{Oe}$ & $6-5$ & 0.13 & $\mathrm{ND}$ & $\mathrm{ND}$ & 45.1 & 28.1 \\
$\mathrm{Oa}$ & $5-0$ & 0.16 & $\mathrm{ND}$ & 4.2 & 40.8 & 27.2 \\
$\mathrm{AE}$ & $0-20$ & 0.85 & 60 & 3.8 & 4.7 & 21.3 \\
$\mathrm{Bh}$ & $20-45$ & 0.91 & 61 & 4.0 & 3.9 & 25.1 \\
$\mathrm{Bs}$ & $45-80$ & 1.10 & 65 & 4.2 & 4.2 & 29.1 \\
\hline
\end{tabular}


2006, we modified the $\mathrm{CO}_{2}$ enrichment system by putting the steel frames and the vertical tubes down to a height of $50 \mathrm{~cm}$ thereby adding $\mathrm{CO}_{2}$ to the dwarf shrubs and lower parts of trees, In addition, laser perforated tubes were woven into the tree crowns and adjusted to match $570 \mathrm{ppm}_{\mathrm{v}} \mathrm{CO}_{2}$ using a portable IRGA. The mean $\mathrm{CO}_{2}$ concentrations under elevated $\mathrm{CO}_{2}$ were $580 \pm 60 \mathrm{ppm}_{\mathrm{v}}$ within the rings and $555 \pm 70 \mathrm{ppm}_{\mathrm{v}}$ in the tree crowns.

\section{Soil warming}

The warming experiment was installed in half of the plots (10 at ambient $\mathrm{CO}_{2}$ and 10 at elevated $\mathrm{CO}_{2}$ ) during summer 2006. On the ground surface of each plot, woven under the aboveground shoots of the dwarf shrubs, $26 \mathrm{~m}$ of $420 \mathrm{~W}$-heating cables (SPSS004026, Chromalox-ETIREX, Soissons, France) were laid out in spirals with a $5 \mathrm{~cm}$ distance between neighbouring cables. Preliminary tests were conducted during 2005 and 2006 to determine the cable length, density and power required to achieve the target temperature, while at the same time assuring that maximum cable surface temperatures would not exceed $45^{\circ} \mathrm{C}$. The $4 \mathrm{~K}$ soil warming treatment was achieved by switching the power supply on and off in 1 min intervals and was applied continuously (day and night). In 2007, the warming treatment began directly after snowmelt (23rd May) and was switched off just before the site was covered in snow for winter (17th October) to avoid an interaction between soil temperature and snowmelt or snow cover.

Sampling and field measurements

Air and soil temperatures were measured at $-3,-5$ and $-10 \mathrm{~cm}$ in the soil plus 5, 10, 20, 100 and $200 \mathrm{~cm}$ in $4-10$ plots per warming treatment using temperature sensors (Hobo Pro v2, Onset Computer Corporation and ibuttons, Maxim Integrated Products DS1922L). Air humidity was measured with ibutton DS1923 sensors. Volumetric soil moisture was repeatedly measured by Frequency Domain Reflectometry with a Theta sonde ML2x probe (Delta-T, UK) at fixed locations in all 40 plots. Readings were converted using a soil-specific equation derived from a lab calibration with soil from all groups. Gravimetric soil moisture was determined in mid July 2007 by taking five soil samples $(0-5 \mathrm{~cm}$ depth) per plot with a soil corer $(2 \mathrm{~cm})$ and measuring the decrease in weight after drying soil samples at $105^{\circ} \mathrm{C}$.

Soil solution was collected in all plots by installing two ceramic suction cups (SoilMoisture Equipment Corp., Santa Barbara, USA) per plot at 3-7 cm depth. All suction cups were located within the Oa horizon that dominated the organic layer. At each sampling event, we collected soil water by evacuating suction cups with a constant $400 \mathrm{hPa}$ for about $16 \mathrm{~h}$ (overnight). In addition to the suction cups, we installed zero-tension lysimeters $(8 \times 8 \mathrm{~cm}$ plexiglass plates with a PE-net) at $5 \mathrm{~cm}$ soil depth. The sampling devices were installed at a fixed depth because space within the $1.1 \mathrm{~m}^{2}$ plots was too limited to open pits for identifying diagnostic horizons. All lysimeters were connected to 1-1 glass bottles buried in the ground. After collection, soil water samples were stored in cooling boxes for transport to the institute for analysis.

\section{$\mathrm{CO}_{2}$-efflux from soils and its $\delta^{13} \mathrm{C}$}

Soil respiration was measured in the field with permanently installed PVC collars (10-cm ID and a height of $5 \mathrm{~cm}$ ) and a LI-COR 6400-09 soil chamber connected to a LI-COR-820 portable system for data collection. One PVC collar per plot (total $n=40$ ) was pressed to a depth of $2 \mathrm{~cm}$ into the organic layer in between dwarf shrubs in the middle of the plots. Soil respiration rates were estimated from increases in $\mathrm{CO}_{2}$ concentrations with time after scrubbing the chamber air to ambient $\mathrm{CO}_{2}$ levels. The pump rate through the system was kept small with $0.2 \mathrm{ml} \mathrm{min}{ }^{-1}$. For ${ }^{13} \mathrm{CO}_{2}$ measurements, we closed the chambers with PVC-lids at least $4 \mathrm{~h}$ after stopping the $\mathrm{CO}_{2}$ enrichment to avoid contamination with ${ }^{13} \mathrm{C}$-depleted $\mathrm{CO}_{2}$. Twenty to thirty minutes after closing the collars, we took gas samples by retrieving $15 \mathrm{ml}$ of air with $20 \mathrm{ml}$ syringe through a septum and by injecting the air in $12 \mathrm{ml}$ preevacuated glass vials closed with an airtight rubber septum (volume of $12 \mathrm{ml}$, Exetainer gas testing vials, Labco Limited, High Wycombe, UK). The glass vials were evacuated with a vacuum of $800 \mathrm{hPa}$ immediately before the sampling.

Plant shoot growth was measured in order to estimate carbon uptake and how the 1-year warming treatment affected $\mathrm{C}$ balance at the site (see calculations below). The length of all new shoots of both 
tree species was measured during early autumn of 2006 and 2007. For the dominant dwarf shrubs Vaccinium myrtillus, V. uliginosum and Empetrum hermaphroditum, three measurements of each species per plot were used to estimate mean 2006 and 2007 shoot growth.

\section{Chemical analysis}

All solution samples from the field were passed through $0.45-\mu \mathrm{m}$ cellulose-acetate filters (Schleicher \& Schuell, ME25) within 2 days of collection and then stored at $4{ }^{\circ} \mathrm{C}$ until analysis. Microbial biomass was determined with the chloroform-fumigationextraction method (Vance et al. 1987) using a soil:solution ratio of 1:5 for the extraction with $0.5 \mathrm{M} \mathrm{K}_{2} \mathrm{SO}_{4}$. Concentrations of dissolved organic C in soil extracts and waters were determined with a TOC/TN analyser (TOC-V Shimadzu Corp. Tokyo, Japan).

\section{Stable isotopes}

The $\delta^{13} \mathrm{C}$ values of soil $\mathrm{CO}_{2}$ were measured with a gasbench II linked to a mass spectrometer (Delta Plus XL, Thermo Finnigan, Bremen interfaced with a Delta-S Finnigan MAT, Bremen, Germany) after depressurising the vials with a needle (Joos et al. 2008). $\mathrm{CO}_{2}$ concentrations of gas samples were calculated from the calibration line with standard gas samples of known $\mathrm{CO}_{2}$ concentrations (340 and $5,015 \mathrm{ppm}$ ). Results of the $\mathrm{C}$ isotope analysis were expressed in $\delta$ units (\%). The $\delta^{13} \mathrm{C}$ values were referenced to the Pee Dee Belemnite (PDB) standard.

\section{Calculations and statistics}

\section{Net plant C uptake}

The warming effect on net $\mathrm{C}$ uptake by plants was roughly estimated by multiplying measured growth effects by estimates of plant biomass production. Biomass accumulation by trees was obtained by first estimating growth functions from measured tree height changes $0,4,6,10,15,20$, and 30 years after planting seedlings at the Stillberg site (Senn and Schönenberger 2001; P. Bebi and C. Rixen, unpublished data). The fitted functions were then applied to the trees in the soil warming experiment. Finally, species-specific allometric regressions between height and total biomass (aboveground and coarse roots) based on 25 trees excavated at the study site (Bernoulli and Körner 1999) were used to calculate the net increase in tree biomass from 2006 to 2007. Biomass productivity of dominant dwarf shrubs in 2007 was similarly calculated from shoot length measurements, applying allometric relationships established from understory plots at the Stillberg site $(n=21)$ (M. Martin and S. Wipf, unpublished data). Fine root productivity for all plants combined, not included in the above calculations, was determined from ingrowth core data and

${ }^{13} \mathrm{C}$ measurements of fine roots (Handa et al. 2008). For both trees and dwarf shrubs, net $\mathrm{C}$ uptake by plants was calculated by multiplying biomass by 0.5 .

Temperature dependencies of soil respiration and DOC concentrations were estimated by the $Q_{10}$ function:

$R=R_{10} \times Q_{10}^{((T-10) / 10)}$.

In which $R$ is the measured soil respiration or DOC concentration, $R_{10}$ is the simulated soil respiration or DOC concentration at $10^{\circ} \mathrm{C}, Q_{10}$ is the temperature sensitivity (over a range of $10^{\circ} \mathrm{C}$ ), and $T$ is the soil temperature. The $R_{10}$ and $Q_{10}$ were estimated by fitting measured data using the Levenberg-Marquard algorithm (Origin 7.0, OriginLab).

Annual soil $\mathrm{CO}_{2}$ effluxes were calculated from applying the fitted $Q_{10}$ functions to measured mean daily soil temperatures for each of the plots.

\section{Stable isotopes}

The $\delta^{13} \mathrm{C}$ of soil-respired was calculated by a mixing model with the sampled $\mathrm{CO}_{2}$ from the soil chambers being composed of ambient $\mathrm{CO}_{2}$ and soil respired $\mathrm{CO}_{2}$ (Subke et al. 2004). The fraction of soil-respired 'new' $\mathrm{C}\left(f_{\text {new }}\right)$ derived from the $\mathrm{CO}_{2}$ addition (being respired from the rhizosphere or litter) was calculated by relating the difference in ${ }^{13} \mathrm{C}$ of respired $\mathrm{CO}_{2}$ between ambient and elevated $\mathrm{CO}_{2}$ to the difference in ${ }^{13} \mathrm{C}$ in plant leaves (mean of tree needles and dwarf shrub leaves). 


$$
f_{\text {new }}=\frac{\left(\delta 13 \mathrm{C}_{\text {flux, pool, elevated }}-\delta 13 \mathrm{C}_{\text {flux, pool, ambient }}\right)}{\left(\delta 13 \mathrm{C}_{\text {plant, elevated }}-\delta 13 \mathrm{C}_{\text {plant, ambient }}\right)}
$$

\section{Statistics}

Effects of $\mathrm{CO}_{2}$ enrichment and warming on all measured parameters were tested by ANOVA using a full factorial split-plot model. Analyses were performed with R. Concentrations of DOC, DON, and in situ soil respiration were log transformed before the analysis. The warming effect was calculated by dividing warmed and control treatments in 2007 and relating this ratio to the one in the pre-warming year 2006. Standard errors were estimated by laws of error propagation.

\section{Results}

Temperatures and moisture

The experimental warming at the soil surface resulted in a mean increase in soil temperatures by $4.7 \pm 0.8$, $3.7 \pm 0.2$ and $3.2 \pm 0.2 \mathrm{~K}$ at 3,5 , and $10 \mathrm{~cm}$ depth, respectively (Means \pm Standard error; Fig. 1). Air temperatures were increased by $4.3 \pm 1.3,2.6 \pm 0.5$ and $0.9 \pm 0.1 \mathrm{~K}$ at 5,10 and $20 \mathrm{~cm}$ height above ground. No air warming effect was detected at tree canopy heights of 100 and $200 \mathrm{~cm}$ (data not shown). Diurnal temperature fluctuations were more pronounced at 5 than at $10 \mathrm{~cm}$ soil depth (Fig. 1), but did not differ between warmed and control plots. The relative warming effect was consistent throughout the snowfree period and did not change with weather or soil moisture conditions. Mean air humidity at $10 \mathrm{~cm}$ height was $90 \pm 1 \%$ in control plots and $81 \pm 2 \%$ in warmed plots. As a result of the warming, soil moisture decreased during the growing season (Fig. 2). In the late growing season 2008, volumetric water contents at 0 to $10 \mathrm{~cm}$ depths were approximately $20 \%$ lower in the warmed than in the control plots. Averaged across the growing season, the warming effect on volumetric soil water content was $15 \%(P<0.05)$. Gravimetric water content in mid July was decreased by $18 \pm 6 \%$ due to the warming. The decline in soil moisture was significant when standardized to pre-season values. Elevated

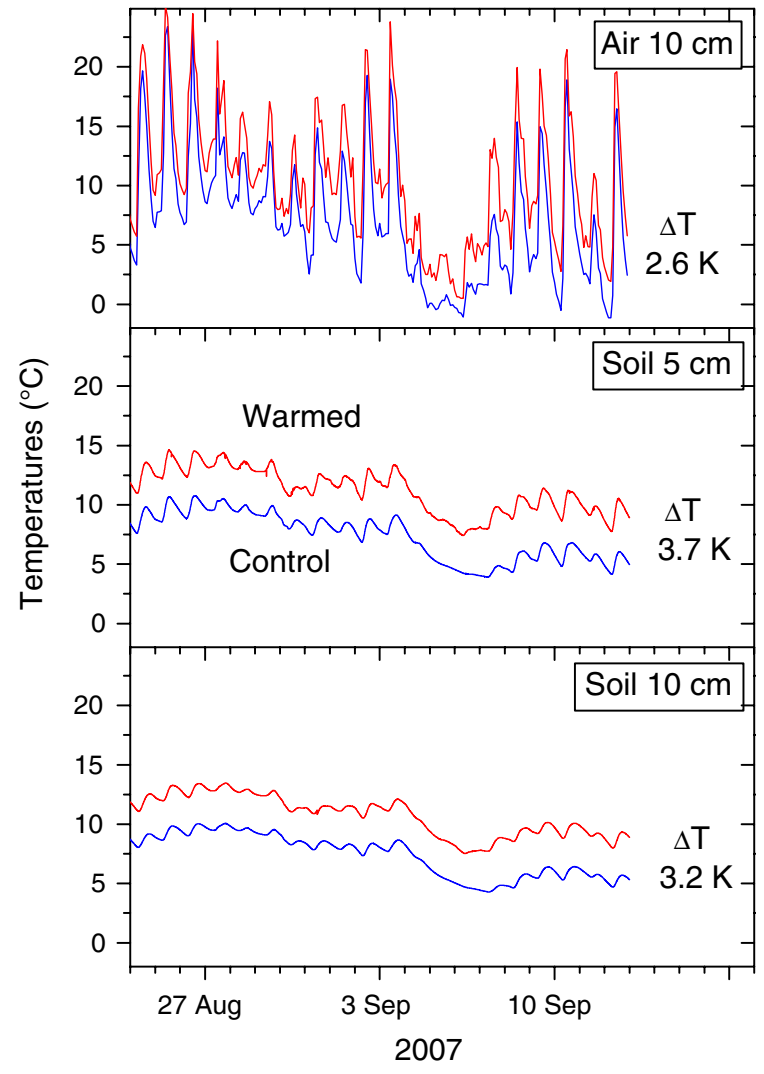

Fig. 1 Effects of experimental warming at the soil surface on air and soil temperatures in late summer 2007. The blue line represents control plots, the red one warmed plots. Mean values of $8-10$ plots per treatment (Color figure online)

$\mathrm{CO}_{2}$ did not affect soil moisture, regardless of soil warming treatment.

Soil respiration and DOC leaching

Ambient temperatures 2004-2007. $\mathrm{CO}_{2}$ effluxes from soils and concentrations of DOC in Oa horizons at $5 \mathrm{~cm}$ depth differed in their dependence on soil temperature (Fig. 3). While soil respiration closely followed an Arrhenius-type relationship with temperature, DOC concentration correlated only weakly with temperature. Calculated $Q_{10}$ for overall soil respiration was $3.0 \pm 0.4\left(r^{2}=0.66 ; P<0.001\right)$ whereas that for DOC concentration was $1.2 \pm 0.1$ $\left(r^{2}=0.27 ; P<0.05\right)$. Frequent monitoring of $\mathrm{CO}_{2}$ effluxes throughout 2007 indicated lower respiration rates at a given temperature in the early than in the late growing season (Fig. 4). 


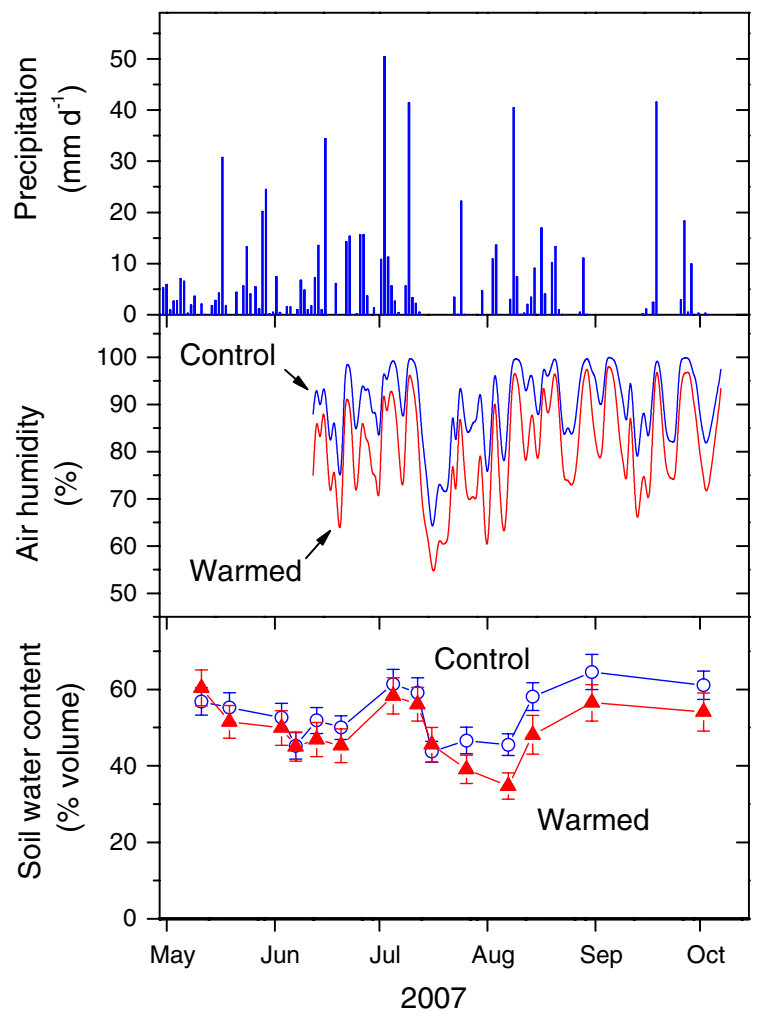

Fig. 2 Effects of experimental soil warming on air humidity at $10 \mathrm{~cm}$ height and volumetric soil water contents at $0-10 \mathrm{~cm}$ depth in 2007. Air humidity values are means of nine plots, soil water content values are the means and standard error of 20 plots

Responses to soil warming

In the pretreatment period 2004-2006, soil respiration rates differed by not more than $5 \%$ between control and warmed plots. During the 5-month growing season in 2007, soil warming by $4 \mathrm{~K}$ increased soil $\mathrm{CO}_{2}$ effluxes by $30-100 \%$ with a mean increase of $45 \%(P<0.05$; Fig. 4). The warming effect on soil respiration did not change throughout the summer. In mid July, however, there was a short dry period during which experimental soil warming had negligible impacts on soil respiration. The temperature dependency of soil respiration was not affected by the soil warming. In the 2007 growing season, overall $Q_{10} \mathrm{~s}$ were $2.5 \pm 1.2$ at ambient temperatures and $2.6 \pm 0.8$ in $4 \mathrm{~K}$ warmer soils. Soil warming increased soil respiration rates despite slightly negative effects on microbial biomass (not

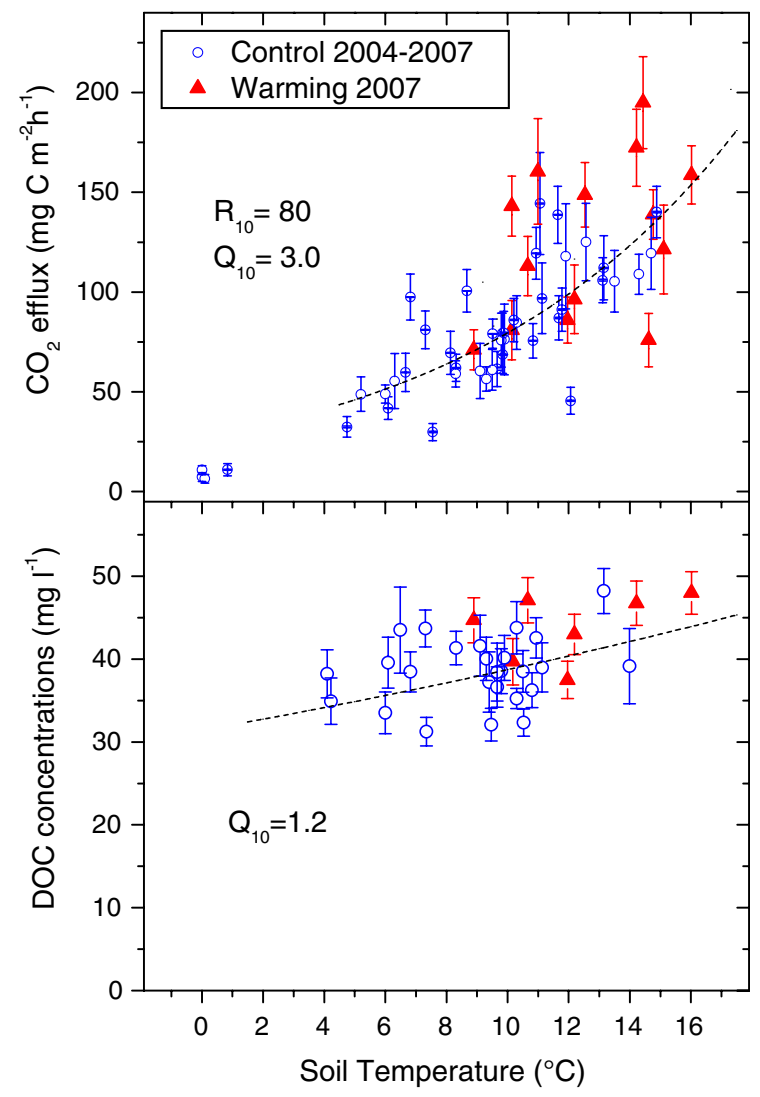

Fig. 3 The relationship between soil temperatures at $5 \mathrm{~cm}$ depth and DOC concentrations and soil respiration rates. Means and standard errors of 20 plots

significant; Fig. 7), indicating that the warming stimulated the activity but not the quantity of soil microbes.

Applying the fitted $Q_{10}$ functions to measured soil temperatures indicated that annual $\mathrm{CO}_{2}-\mathrm{C}$ effluxes were $\quad 300 \pm 30 \mathrm{~g} \mathrm{C} \mathrm{m}^{-2} \mathrm{y}^{-1} \quad$ (Mean \pm Standard error) in the pretreatment year 2006 and $350 \pm 40 \mathrm{~g} \mathrm{C} \mathrm{m}^{-2} \mathrm{y}^{-1}$ in the control plots in 2007 . The greater $\mathrm{CO}_{2}$ effluxes in 2007 were related to a 1-month earlier snowmelt and, thus, to a substantially longer growing season than in the previous year. Experimental soil warming increased further annual soil respiration by $120 \pm 40 \mathrm{~g} \mathrm{C} \mathrm{m}^{-2} \mathrm{y}^{-1}$.

Compared to $\mathrm{CO}_{2}$ effluxes, DOC fluxes were much smaller with $20-35 \mathrm{~g}$ DOC $\mathrm{m}^{-2}$ being leached from the organic layer (Hagedorn et al. 2008). Also, the effects of the $4 \mathrm{~K}$ soil warming on DOC concentrations sampled with suction cups at $5 \mathrm{~cm}$ depth in the 


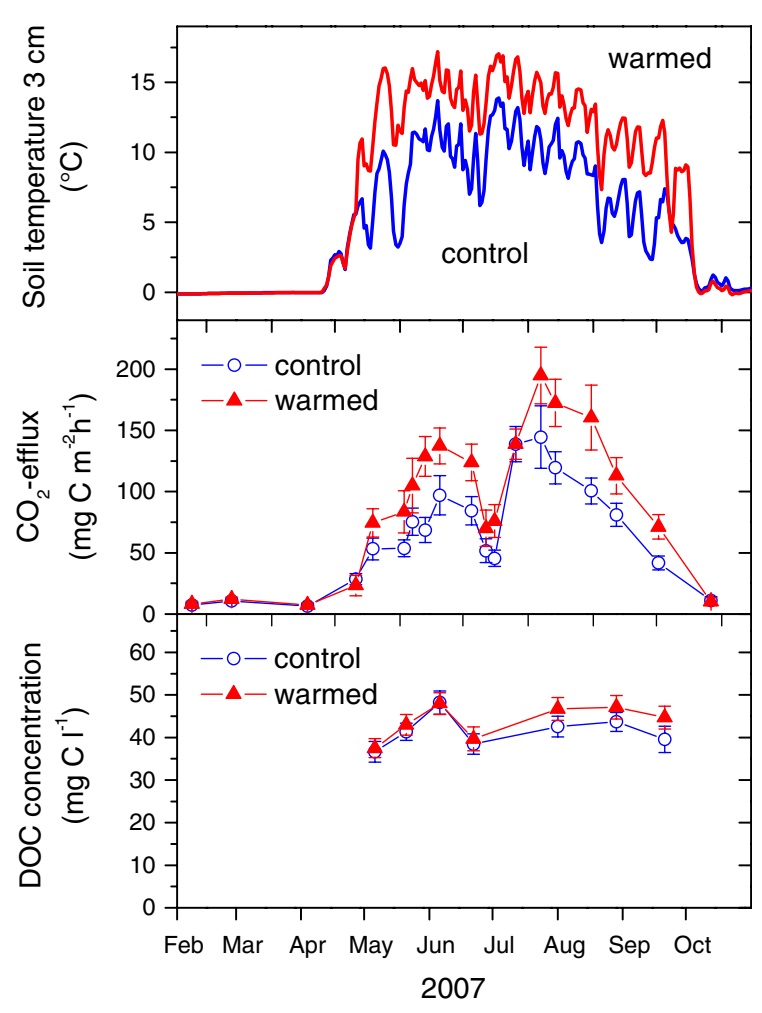

Fig. 4 Effects of $4 \mathrm{~K}$ soil warming on soil respiration rates and DOC concentrations in the $\mathrm{Oa}$ horizon at $5 \mathrm{~cm}$ depth. Means and standard errors of 20 plots

Oa horizons were much smaller than for soil respiration (Fig. 4). Concentrations of DOC were not increased before August, more than 2 months after the warming started, and even then the effect was not significant. In the late growing season, the maximal increase in DOC concentrations was $10 \pm 10 \%$. The results of the zero-tension lysimeter study support these negligible warming effects on DOC concentrations (Fig. 5). In September 2007, after 4 months of soil warming, DOC concentrations at $5 \mathrm{~cm}$ depth were $11 \pm 20 \%$ higher in the warmed than in the unwarmed soils. However, the pre-warming difference of the same lysimeters was $7 \pm 17 \%$.

Soil warming effects on new and old SOM

The addition of $200 \mathrm{ppm}_{\mathrm{v}} \quad \mathrm{CO}_{2}$ depleted in ${ }^{13} \mathrm{C}$ $(-29 \%)$ allowed the tracing of recent plant-derived $\mathrm{C}$ in the plant and soil system. In 2007, the mean decline in ${ }^{13} \mathrm{C}$ in leaves of trees and dwarf shrubs was $-6.7 \pm 0.7 \%$. This isotopic signal was clearly

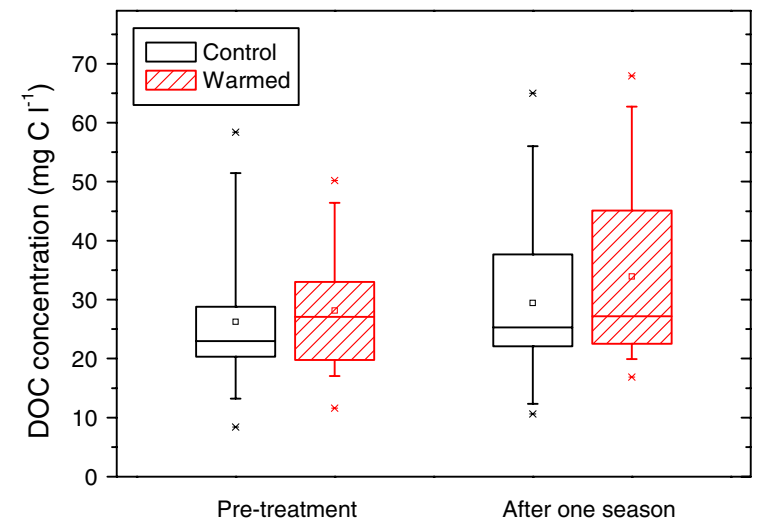

Fig. 5 Effects of $4 \mathrm{~K}$ soil warming on DOC concentrations in leachates of zero-tension lysimeters at $5 \mathrm{~cm}$ depth. Means and standard errors of 40 plots

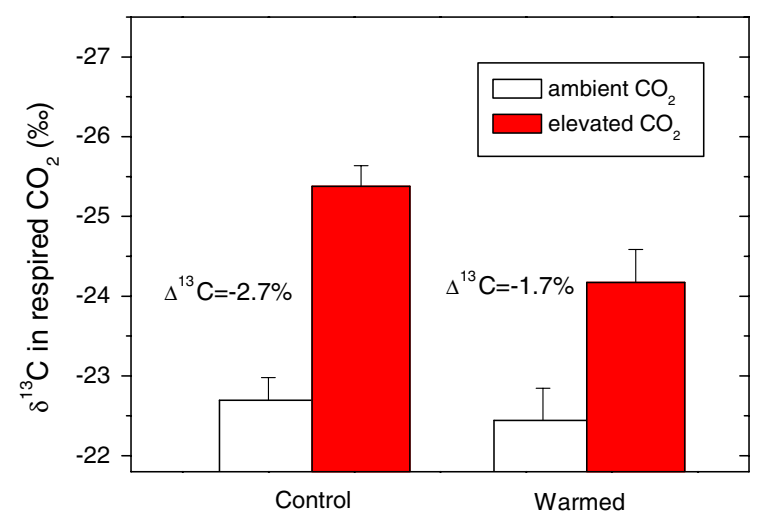

Fig. 6 Effects of $4 \mathrm{~K}$ soil warming on $\delta^{13} \mathrm{C}$ values of soilrespired $\mathrm{CO}_{2}$. The $\mathrm{CO}_{2}$ enrichment decreased air $\delta^{13} \mathrm{C}$ values by $6.7 \%$. Means and standard errors of 10 plots

reflected in soil-respired $\mathrm{CO}_{2}$ but was significantly smaller in the warmed than in the unwarmed soils (Fig. 6). Assuming a simple mixing model (equation 2) suggests that the contribution of new plant-derived $\mathrm{C}$, either through rhizosphere respiration or through decomposing new litter, was approximately $40 \%$ in the unwarmed soils but only $25 \%$ in the warmed soils (averaged across seven sampling campaigns throughout the season). Multiplying these fractions of recent $\mathrm{C}$ with measured $\mathrm{CO}_{2}$ effluxes suggests that the increased soil respiration rates from warmed soils were solely related to an accelerated mineralization of old soil carbon, while respiration rates from new plant-derived $\mathrm{C}$ remained constant. We might have underestimated the respiration losses from 
root-derived $\mathrm{C}$ as the collars for measuring $\mathrm{CO}_{2}$ effluxes were placed in between dwarf shrubs and thus, at microsites with smaller root densities and since some roots might be supplied with plantderived $\mathrm{C}$ from outside the plots. However, because $\mathrm{CO}_{2}$ effluxes were measured in the same way in both treatments, such potential underestimates would not influence the warming effect on respiration of new $\mathrm{C}$. In addition, they would not affect respiration rates from old soil $\mathrm{C}$.

C uptake by plants

Soil warming for one season caused slight increases in shoot growth of trees (larch $+17 \pm 34 \%$, pine $12 \pm 32 \%)$ and dwarf shrubs $(+14 \pm 12 \%)$, though no increases were statistically significant (Fig. 7). Regarding larch, total shoot growth per tree during 2007, the first season of warming, was on average only half of growth in the previous year due to damage from an early summer frost event. Our growth data allows a first rough extrapolation of growth data to net annual $\mathrm{C}$ uptake by plants: calculated growth rates indicated annual net $\mathrm{C}$ uptake rates of 20-40 $\mathrm{g} \mathrm{C} \mathrm{m}^{-2} \mathrm{y}^{-1}$ for the 32-year old treeline trees. Biomass calculations of dwarf shrubs suggested an annual shoot growth production of 40-150 (mean $=90) \mathrm{g} \mathrm{C} \mathrm{m}^{-2} \mathrm{y}^{-1}$ for the experimental plots

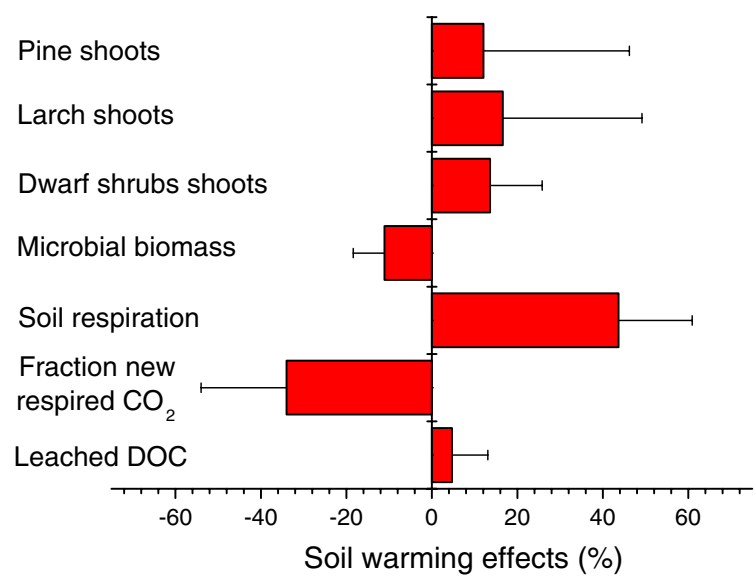

Fig. 7 Effects of the one-season soil warming by $4 \mathrm{~K}$ on shoot growths of pine, larch, and dwarf, on soil microbial biomass pool, on soil respiration rates, on fractions of new $\mathrm{C}$ (litter + roots) in soil-respired $\mathrm{CO}_{2}$, and on mean DOC concentrations. The effect was calculated by relating warmed/control treatments to the pre-warming year 2006. Means and standard errors of 20 plots
(M. Martin and S. Wipf, unpublished data). Ingrowth core data and recovery of the added ${ }^{13} \mathrm{C}$-depleted $\mathrm{CO}_{2}$ in roots indicated a fine root production of $75 \mathrm{~g} \mathrm{C} \mathrm{m}^{-2} \mathrm{y}^{-1}$ (Handa et al. 2008). In total, this yields a total net annual $\mathrm{C}$ uptake by the treeline vegetation of $200-250 \mathrm{~g} \mathrm{C} \mathrm{m}^{-2} \mathrm{y}^{-1}$. When we assume that overall plant $\mathrm{C}$ uptake responds similarly to warming as shoot growth, the warming-induced stimulation of net $\mathrm{C}$ uptake was between 20 and $40 \mathrm{~g} \mathrm{C} \mathrm{m}^{-2} \mathrm{y}^{-1}$. A more comprehensive study of growth responses, including belowground production and stem diameter increases, over a longer period are needed to validate this estimate.

\section{Discussion}

Contrasting response of $\mathrm{C}$ fluxes to warming

The experimental warming created temperature increases that were comparable with those experienced in the warm European summers of 2003 and 2006: in June and August 2003 and July 2006, temperature anomalies reached more than $6 \mathrm{~K}$ over major parts of Central Europe (Luterbacher et al. 2004; Rebetez et al. 2009). Our treatment resulted in a quite homogenous soil warming down to a soil depth of at least $10 \mathrm{~cm}$ where more than $90 \%$ of the roots (Handa et al. 2008) and most of the labile $\mathrm{C}$ in the organic layer are located (Bednorz et al. 2000). Warming also induced a decline in soil moisture by 15-20\% (relative), which was comparable to the 10$20 \%$ drier soils in our experiment during the heat wave of 2003 compared to other years (F. Hagedorn, unpublished data).

Our results showed distinctly different effects of experimental soil warming on $\mathrm{C}$ fluxes in the plant and soil system. In the soil, $\mathrm{CO}_{2}$ efflux was closely linked to soil temperature and showed instantaneous responses to experimental warming as well as sustained stimulations over one growing season. In contrast, warming had little effect on DOC leaching with no immediate responses at the beginning of the warming treatment and an overall insignificant 5\%increase after one growing season.

The strong temperature dependency of soil respiration at short and longer time scales is consistent with other field and lab studies (e.g., Kirschbaum 1995; Schindlbacher et al. 2009). It supports the 
theoretically expected tight relationship between biochemical processes and temperature below critical temperatures as long as other factors such as moisture are not co-limiting (Davidson and Janssens 2006). In fact, the sustained temperature stimulation of soil respiration observed here across the whole season suggests that soil moisture was not an important colimiting factor at our study site with well-drained sandy soils and 1,100 mm of annually well-distributed rainfall. As a consequence, the $15 \%$-decline in soil moisture induced by the warming did not significantly reduce the response of soil respiration except for a 2-week dry and hot period mid July 2007 (Fig. 4). Our field-based $Q_{10}$ of soil respiration of 2.5-3 during the growing season agreed well with the $Q_{10}$ of 2.5 estimated in a laboratory incubation of soils of the study site (Reichstein et al. 2000). The extrapolation of our soil respiration measurements using the fitted $Q_{10}$ functions suggests that the $4 \mathrm{~K}$ warming increased the annual $\mathrm{CO}_{2}$ efflux in 2007 by $120 \mathrm{~g} \mathrm{CO}_{2}-\mathrm{Cm}^{-2} \mathrm{y}^{-1}$ which is $40-50 \%$ higher than what was calculated for the control plots. In relative terms the increase in soil respiration we measured was similar to the initial responses to a $5 \mathrm{~K}$ warming in a montane forest in Austria (Schindlbacher et al. 2009), but higher than the $24-43 \%$ increase in boreal forests (Niinistö et al. 2004; Bronson et al. 2008) and the $20-35 \%$ increase in the temperate Harvard Forest (Melillo et al. 2002). However, since $\mathrm{CO}_{2}$ efflux rates at our alpine treeline site were smaller than those measured in the other forests with more moderate climates and longer growing seasons, the absolute increase in respired $\mathrm{C}$ due to soil warming was lower in our study. Niinistö et al. (2004) and Melillo et al. (2002) showed that the response of soil $\mathrm{CO}_{2}$ efflux strongly declined after one, respectively 5 years of treatment very likely due to depletion in labile soil carbon. At the alpine treeline, however, we would expect longer lasting warming effects because the 5-20 cm thick organic layer stores particularly large amounts of SOM (4-20 kg C m${ }^{-2}$ ), which is predominantly non-stabilized and readily decomposable (Reichstein et al. 2000).

Soil warming induces $\mathrm{C}$ losses

While $\mathrm{C}$ losses via soil respiration responded strongly to warming, ecosystem $\mathrm{C}$ gains by plant growth were only slightly affected in this first treatment year (Fig. 7). It is not surprising that plants showed relatively small growth responses in the first growing season because most plant species present at our site are characterized by determinate growth, and response time to changing growth conditions are likely to lag behind at least one growing season (Hartley et al. 1999; Danby and Hik 2007). Also, our treatment did not warm the air above the dwarf shrub layer. We think, however, that the lack of warming the tree canopy is relatively unimportant, because it is mostly the rooting zone temperature that determines tree growth at treeline (Körner 1998). Responses during the hot year 2003 support our results, when tree growth at our site and in other Swiss alpine and subalpine forests was hardly affected by a 5-6 K warmer growing season (Jolly et al. 2005; Handa et al. 2006), whereas soil respiration was accelerated (F. Hagedorn, unpublished data). We therefore conclude that our findings of net $\mathrm{C}$ losses from the warmed plots are indeed representative for stochastically occurring hot years. However, it remains to be shown whether or not the net $\mathrm{C}$ balance in the following years will change due to potential longterm plant growth responses to warming or due to declining substrate availability in soils.

The consequences of the stronger response of soil $\mathrm{CO}_{2}$ effluxes for the ecosystem net $\mathrm{C}$ balance depend on which one of the two major components of soil respiration was driving the increase in soil respiration. If the autotrophic component (i.e., plant roots) was stimulated, then the increase in soil respiration would simply mean a faster $\mathrm{C}$ cycling rate through the plant and soil system. A greater heterotrophic respiration, however, would signify an increased $\mathrm{C}$ loss from soil organic matter. The ${ }^{13} \mathrm{C}$ tracing provided clear evidence for a stronger response of the heterotrophic component to the soil warming. The difference in $\delta^{13} \mathrm{C}$ of soil-respired $\mathrm{CO}_{2}$ was reduced in the warmed plots (Fig. 6), indicating that the relative contribution of recent plant-derived $\mathrm{C}$ to soil respiration declined by about $40 \%$ (Fig. 7). Therefore, our results show that the $4 \mathrm{~K}$ soil warming particularly increased the mineralization of more than 7 year-old SOM and hence, the warming turned the treeline ecosystem into a $\mathrm{C}$ source rather than simply causing faster $\mathrm{C}$ cycling.

Our results allow a rough estimate of the initial net $\mathrm{C}$ losses by the soil warming. 
Relating the small growth response of about $15 \%$ to net primary productivity of about 200-250 $\mathrm{g} \mathrm{C} \mathrm{m}^{-2} \mathrm{y}^{-1}$ including roots (M. Martin and S. Wipf, unpublished data), being typical for closed alpine vegetation (Körner 2003), suggests that the warming-induced increase in plant $\mathrm{C}$ uptake amounted to $30-40 \mathrm{~g} \mathrm{C} \mathrm{m}^{-2} \mathrm{y}^{-1}$. This is about one-third of the acceleration in soil $\mathrm{CO}_{2}$ efflux from warmed soils via respiration. A stronger warmingresponse of roots than shoots could have biased the estimated increase in plant $\mathrm{C}$ uptake. However, our data suggests that roots were rather less responsive because respiration rates of new $\mathrm{C}$ (largely from roots) were not affected by the warming. This conclusion is supported by decreasing root biomass in heated soils of a boreal forest (Bronson et al. 2008). In our study, the difference between increased SOM mineralization and plant $\mathrm{C}$ uptake indicates that soil warming increased net $\mathrm{C}$ losses by about 80 $110 \mathrm{~g} \mathrm{C} \mathrm{m}^{-2} \mathrm{y}^{-1}$, which corresponds closely to the net $\mathrm{C}$ losses of $100 \mathrm{~g} \mathrm{C} \mathrm{m}^{-2} \mathrm{y}^{-1}$ in response to warming of a montane meadow in Colorado by $1.5 \mathrm{~K}$ (Saleska et al. 1999). However, in contrast to our study, their result was attributed to the indirect warming effect of declining soil moisture in the dry meadow receiving only $150 \mathrm{~mm}$ of summer precipitation. Drought conditions induced by their treatment dampened the increase in soil respiration but negatively affected plant $\mathrm{C}$ uptake, resulting in a net $\mathrm{C}$ loss in warmed plots. In comparison to the Colorado study, mean rainfall during the vegetation period is four times higher at our site and amounted to $550 \mathrm{~mm}$ even in the very dry summer of 2003. Soil moisture is not considered a limiting factor for plant growth in treeline systems of this region (Körner 2003), which is also supported by no measurable effects of the 2003 drought on tree growth (Handa et al. 2006). Moreover, soil moisture rarely limited soil respiration during our experiment, as indicated by the similar temperature dependency of respiration in warmed and control plots. Most other parts of the Alps receive even more precipitation than our site located in the relatively dry Inner Alps (Federal Office for Water and Geology 2001). We therefore expect increased C losses due to warming-induced acceleration in soil respiration at most alpine treeline sites as the frequency of hot and dry summers will likely increase during the next century (Stott et al. 2004).
Negligible response of DOC leaching

Temperature apparently did not control leaching of DOC to the same extent as soil respiration. There was no immediate response of DOC concentration to increased temperature, a relatively week $10 \%$ increase after 2 months of experimental warming, and essentially no seasonal variation in response to differences in temperature. Because warming will decrease drainage, the absolute amount of DOC leached from the organic layer was very likely even less affected. A poor relationship between temperature and DOC leaching on a seasonal basis has been observed previously in field studies in temperate forests which was attributed to the stronger impact of water fluxes than temperature per se, or to seasonally changing DOC sources (Michalzik et al. 2001). In a preliminary warming test in 2006, we excluded water fluxes as a potential co-driver for DOC leaching by regularly irrigating soils, and found the same lack in response as in 2007 (F. Hagedorn, unpublished data). The impact of varying 'fresh' DOC inputs, also is considered to be negligible in our study, as we directly compared warmed with untreated soils. Despite the fact that we can largely exclude potential confounding factors, soil warming still had only negligible effects on DOC concentrations in the Oa horizons. At first glance, this seems surprising because DOC production is thought to be mediated by microbial activity (Christ and David 1996; Kalbitz et al. 2000) and thus, we would expect that DOC concentrations increase with increasing temperatures. One explanation for the apparent minor direct control by temperature could be that microbial-driven DOC generation rates are small compared to the total pool of leachable DOC. Consequently, the DOC pool might build-up over relatively long time periods, and any temperature-driven microbial effects would only be observable in the longer term. The increase in DOC leaching after 2 months of warming supports a delayed DOC response (Fig. 4), which is consistent with time-lags of about 2 months between DOC leaching and temperature observed in a seasonal monitoring study and in transplant experiments with soil cores (Fröberg et al. 2006; Harrison et al. 2008). However, our study suggests that other mechanisms must also have contributed because in late summer, after 4 months of soil warming and after substantial 
amounts of DOC (10-15 $\left.\mathrm{g} \mathrm{DOC} \mathrm{m}^{-2}\right)$ had been leached, the warming effect on DOC leaching was still substantially smaller than the effect on soil respiration. Perhaps the production and consumption of DOC were tightly balanced, resulting in negligible net changes in DOC leaching. Laboratory studies by Marschner \& Bredow (2002) with agricultural soils corroborate this mechanism; they show that contents of extractable DOC even decrease with rising temperatures due to the utilization of labile DOC by microorganisms.

\section{Conclusion}

Our results indicate that net $\mathrm{C}$ uptake by plants, soil respiration and DOC leaching in an alpine treeline ecosystem responded very differently to a $4 \mathrm{~K}$ temperature increase over one season. While soil respiration rates increased instantaneously with increased temperature, DOC leaching showed a delayed and much smaller response, probably due to a balancing out of DOC production and degradation. Tracing of ${ }^{13} \mathrm{C}$ depleted $\mathrm{CO}_{2}$ added for 7 years showed that the accelerated $\mathrm{CO}_{2}$ effluxes from warmed soils were not driven by increased mineralization of recent plant litter and root respiration but by mineralization from older soil organic matter. These soil C losses clearly exceeded the estimated $\mathrm{C}$ accumulation by plants, which showed little response to one growing season of soil warming. We conclude that soil warming being representative for hot but also drier years leads to $\mathrm{C}$ losses from alpine treeline ecosystems.

Acknowledgments We thank K. Wetter, A. Moser, M. Pohl, and R. Köchli for their field assistance, N. Hajar for measuring DOC concentrations. The research platform Stillberg was financed by Velux foundation and a French "ANRbiodiversité" grant (project "Qdiv" led by Paul Leadley). M. Martin was supported by the Swiss National Science Foundation (SNF; grant 315200-116861).

\section{References}

Bednorz F, Reichstein M, Broll G et al (2000) Humus forms in the forest-alpine tundra ecotone at Stillberg (Dischmatal, Switzerland): spatial heterogeneity and classification. Arct Antarct Alp Res 32:21-29. doi:10.2307/1552406

Bernoulli M, Körner C (1999) Dry matter allocation in treeline trees. Phyton 39:7-12
Bronson DR, Gower ST, Tanner M et al (2008) Response of soil surface $\mathrm{CO}_{2}$ flux in a boreal forest to ecosystem warming. Glob Change Biol 14:856-867. doi:10.1111/j.13652486.2007.01508.x

Christ MJ, David MB (1996) Temperature and moisture effects on the production of dissolved organic carbon in a Spodosol. Soil Biol Biochem 28:1191-1199. doi:10.1016/ 0038-0717(96)00120-4

Ciais P, Reichstein M, Viovy N (2005) Europe-wide reduction in primary productivity caused by the heat and drought in 2003. Nature 437:529-533. doi:10.1038/nature03972

Danby RK, Hik DS (2007) Responses of white spruce (Piceea glauca) to experimental warming at a subarctic alpine treeline. Glob Change Biol 13:437-451. doi:10.1111/j.13652486.2006.01302.x

Davidson EA, Janssens IA (2006) Temperature sensitivity of soil carbon decomposition and feedbacks to climate change. Nature 440:165-173. doi:10.1038/nature04514

Dormann CF, Woodin SJ (2002) Climate change in the Arctic: using plant functional types in a meta-analysis of field experiments. Funct Ecol 16:4-17. doi:10.1046/j.0269-8463. 2001.00596.x

Federal Office for Water and Geology (2001) Hydrological atlas of Switzerland, 6th edn. Bern, Switzerland

Fröberg M, Berggren M, Bergkvist B et al (2006) Concentration and fluxes of dissolved organic carbon (DOC) in three Norway spruce stands along a climatic gradient in Sweden. Biogeochem 77:1-23. doi:10.1007/s10533-0040564-5

Hagedorn F, van Hees PAW, Handa IT et al. (2008) Elevated atmospheric $\mathrm{CO}_{2}$ fuels leaching of old dissolved organic matter at the alpine treeline. Glob Biogeochem Cycles 22:GB2004. doi:10.1029/2007GB003026

Handa TI, Körner C, Hättenschwiler S (2006) Conifer stem growth at the altitudinal treeline in response to four years of $\mathrm{CO}_{2}$ enrichment. Glob Change Biol 12:2417-2430. doi: 10.1111/j.1365-2486.2006.01258.x

Handa TI, Hagedorn F, Hättenschwiler S (2008) No stimulation in root production in response to four years of in situ $\mathrm{CO}_{2}$ enrichment at the Swiss treeline. Funct Ecol 22:348358. doi:10.1111/j.1365-2435.2007.01372.x

Harrison A, Taylor K, Scott A et al (2008) Potential effects climate change on DOC release from three different soil types on the Northern Pennines UK: examination using field manipulation experiments. Glob Change Biol 14:687-702. doi:10.1111/j.1365-2486.2007.01504.x

Hartley AE, Neill C, Melillo JM et al (1999) Plant performance and soil nitrogen mineralization in response to simulated climate change in subarctic dwarf shrub heath. Oikos 86:331-343. doi: $10.2307 / 3546450$

Hättenschwiler S, Handa IT, Egli L et al (2002) Atmospheric $\mathrm{CO}_{2}$ enrichment of alpine treeline conifers. New Phytol 156:363-375. doi:10.1046/j.1469-8137.2002.00537.x

Heimann M, Reichstein M (2008) Terrestrial ecosystem carbon dynamics and climate feedbacks. Nature 451:289-292. doi:10.1038/nature06591

Högberg P, Nordgren A, Buchmann N et al (2001) Large-scale forest girdling shows that current photosynthesis drives soil respiration. Nature 411:789-792. doi:10.1038/35081058

IPCC (2007) Climate change 2007: the physical science basis. In: Solomon S, Qin D, Manning M (eds) Contribution of 
working group I to the fourth assessment report of the intergovernmental panel on climate change. Cambridge University Press, Cambridge

Jenny H (1926) Vegetations-Entwicklung und Bodenbnildung. Zweiter Teil: Die alpinen Böden. Denkschrift Schweizerischen Naturforschenden Ges 63:297-340

Jolly WM, Dobbertin M, Zimmermann NE et al (2005) Divergent vegetation growth responses to the 2003 heat wave in the Swiss Alps. Geophys Res Lett 32:L18409. doi:10.1029/2005GL023252

Joos O, Saurer M, Heim A, et al. (2008) Can we use the $\mathrm{CO}_{2}$ concentrations determined by continuous-flow isotope ratio mass spectrometry from small samples for the Keeling plot approach? Comparison of infrared gas analyser and isotope ratio mass spectrometer measurements. Rapid Commun Mass Spectrom 22:4029-4034

Kalbitz K, Solinger S, Park J-H et al (2000) Controls on the dynamics of dissolved organic carbon in soils: a review. Soil Sci 165:277-304. doi:10.1097/00010694-20000400000001

Kirschbaum MUF (1995) The temperature dependence of soil organic matter decomposition, and the effect of global warming on soil C storage. Soil Biol Biochem 27:753-760

Körner C (1998) A re-assessment of high elevation treeline positions and their explanation. Oecologia 115:445-459. doi: $10.1007 / \mathrm{s} 004420050540$

Körner C (2003) Alpine plant life-functional plant ecology of high mountain ecosystems, 2nd edn. Springer, Heidelberg

Kudo G, Suzuki S (2003) Warming effects on growth, production, and vegetation structure of alpine shrubs: a five-year experiment in northern Japan. Oecologia 135:280-287

Luo Y, Shigiang W, Hui D et al (2001) Acclimatization of soil respiration to warming in a tall grass prairie. Nature 413:622-625. doi:10.1038/35098065

Luterbacher J, Dietrich D, Xoplaki E et al (2004) European seasonal and annual temperature variability, trends, and extremes since 1500. Science 303:1499-1503. doi:10.1126/ science. 1093877

Marschner B, Bredow A (2002) Temperature effects on release and ecologically relevant properties of dissolved organic carbon in sterilised and biologically active soil samples. Soil Biol Biochem 34:459-466

Melillo JM, Steudler PA, Aber JD et al (2002) Soil warming and carbon-cycle feedbacks to the climate system. Science 298:2173-2176. doi:10.1126/science.1074153

Michalzik B, Kalbitz K, Park J-H et al (2001) Fluxes and concentrations of dissolved organic carbon and nitrogena synthesis for temperate forests. Biogeochem 52:173205. doi:10.1023/A:1006441620810

Niinistö SM, Silvola J, Kellomäki S (2004) Soil $\mathrm{CO}_{2}$ efflux in a boreal pine forest under atmospheric $\mathrm{CO}_{2}$ enrichment and air warming. Glob Change Biol 10:1363-1376. doi: 10.1111/j.1365-2486.2004.00799.x

Oberbauer S, Tweedie CE, Welker JM et al (2007) Tundra $\mathrm{CO}_{2}$ fluxes in response to experimental warming across latitudinal and moisture gradients. Ecol Monogr 77:221-238. doi:10.1890/06-0649
Oechel WC, Vourlitis GL, Hastings SL et al (1993) Acclimatization of ecosystem $\mathrm{CO}_{2}$ exchange in the Alaskan Arctic in response to decadal climate warming. Nature 406:978981. doi: $10.1038 / 35023137$

Parsons AN, Welker JM, Wookey PA et al (1994) Growthresponses of 4 sub-arctic dwarf shrubs to simulated environmental change. J Ecol 82:307-318. doi:10.2307/ 2261298

Rebetez M, Reinhard M (2008) Monthly air temperature trends in Switzerland 1901-2000 and 1975-2004. Theor Appl Climatol 91:27-34. doi:10.1007/s00704-007-0296-2

Rebetez M, Doupont O, Giroud M (2009) An analysis of the July 2006 heatwave extent in Europe compared to the record year of 2003. Theor Appl Climatol 95:1-7. doi: 10.1007/s00704-007-0370-9

Reichstein M, Bednorz F, Broll G et al (2000) Temperature dependence of carbon mineralization: conclusions from a long-term incubation of subalpine soil samples. Soil Biol Biochem 32:947-958. doi:10.1016/S0038-0717(00)00002-X

Rustad LE, Campbell JL, Marion GM et al (2001) A metaanalysis of the response of soil respiration, net nitrogen mineralization, and aboveground plant growth to experimental ecosystem warming. Oecologia 126:543-562. doi: $10.1007 / \mathrm{s} 004420000544$

Saleska SR, Harte J, Torn M (1999) The effect of experimental ecosystem warming on $\mathrm{CO}_{2}$ fluxes in a montane meadow. Glob Change Biol 5:125-141. doi:10.1046/j.1365-2486. 1999.00216.x

Schindlbacher A, Zechmeister-Boltenstern S, Jandl R (2009) Carbon losses due to soil warming: do autotrophic and heterotrophic soil respiration respond equally? Glob Change Biol 15:901-913. doi:10.1111/j.1365-2486.2008. 01757.x

Senn J, Schönenberger W (2001) Zwanzig Jahre Versuchsaufforstung Stillberg: Überleben und Wachstum einer subalpinen Aufforstung in Abhängigkeit vom Standort. Schweiz Z Forstwes 152:226-246

Shaver GR, Chapin FSIII, Gartner BL (1986) Factors limiting seasonal growth and peak biomass accumulation in Eriophorum vaginatum in Alaskan tussock tundra. J Ecol 74:257-278. doi: $10.2307 / 2260362$

Sjögersten S, Turner BL, Mathieu N et al (2003) Soil organic matter biochemistry and potential susceptibility to climate change across the forest-tundra ecotone in the Fennoscandian mountains. Glob Change Biol 9:759-772. doi: 10.1046/j.1365-2486.2003.00598.x

Stott PA, Stone DA, Allen MR (2004) Human contribution to the European heatwave of 2003. Nature 432:610-614. doi: 10.1038/nature03089

Subke J-A, Hahn V, Battipaglia G et al (2004) Feedback interactions between needle litter decomposition and rhizosphere activity. Oecologia 139:551-559. doi:10.1007/ s00442-004-1540-4

Vance ED, Brookes PC, Jenkinson DS (1987) An extraction method for measuring soil microbial biomass C. Soil Biol Biochem 19:703-707. doi:10.1016/0038-0717(87)90052-6 